\title{
Kajian Pola Arus Laut dan Distribusi Sedimen Di Perairan Pantai Muara Kamal Jakarta Utara
}

\author{
Permana Ari Soerjawo ${ }^{1}$, Thonas Indra Maryanto ${ }^{2}$ \\ ${ }^{1}$ Pusat Pengkajian dan Perekayasaan Teknologi Kelautan dan Perikanan- KKP \\ Jakarta \\ ${ }^{2}$ Jurusan Teknik Geodesi, Fakultas Teknik Sipil dan Perencanaan, ITENAS, \\ Bandung \\ Email: ari_permana008@yahoo.com, thonas.indra@gmail.com
}

\begin{abstract}
ABSTRAK
Pola arus laut dan distribusi sedimen merupakan proses dinamika di suatu perairan yang mempunyai karakteristik berbeda-beda, sehingga berpengaruh terhadap pembentukan geomorfologi pantai di seluruh dunia. Penelitian ini bertujuan untuk mengetahui pola arus dan sedimen di perairan Pantai Muara Kamal Jakarta Utara di tahun 2012. Data yang digunakan merupakan data primer dan data sekunder, data primer meliputi data arus yang didapat dari pemasangan ADCP(Acoustic Doppler Current Profiler), data pasang surut dan sedimen perairan yang diambil dengan sedimen grab. Data sekunder berupa peta LPI (Lingkungan Pantai Indonesia) tahun 2000 skala 1:50.000 dari BIG (Badan Informasi Geospasial) dan citra satelit Google Earth tahun 2009. Hasil penelitian menunjukan bahwa kecepatan arus yang paling besar terdapat pada lapisan permukaan dengan kecepatan 0,242 m/s kearah barat daya $\left(207,8^{\circ}\right)$, kecepatan arus terkecil terdapat pada lapisan dasar yaitu $0,141 \mathrm{~m} / \mathrm{s}$ kearah barat daya $\left(207^{\circ}\right)$. Hasil simulasi model hidrodinamika 2D, menunjukkan bahwa pada saat pasang arus laut mengarah ke daratan (selatan) dan pada saat surut arus laut mengarah ke laut lepas (barat laut). Berdasarkan kandungan ukuran butir sedimen di perairan Pantai Muara Kamal Jakarta Utara adalah pasir (64.98 - 72.15\%) fraksi pasir tertinggi distasiun B(belakang geotekstil), lanau (24.56 - 29.36\%) fraksi lanau tertinggi di stasiun C (depan geotekstil) dan Lempung (1.64 - 5.64\%) fraksi lempung tertinggi di stasiun C (depan geotekstil).
\end{abstract}

Kata kunci: Arus, Pantai Muara Kamal, Sedimen, model hidrodinamika 2D

\section{ABSTRACT}

Ocean current and sediment distribution are the dynamic process that have different charactheristic and therefore influenced beach geomorfophology around the world. This research aims to understand both ocean current and sediment pattern in Muara Kamal North Jakarta in 2012. This research used primary and secondary data, primary data were consisted of current data from ADCP (Acoustic Doppler Current Profiler), tidal data and bottom sediment samples. Secondary data involved of Indonesia Coastline Environmental map of year 2000 with scale 1:50.000 from Geospatial information Agency and a satellite data from Google earth of year 2009. The results showed that greatest ocean current velocity contained in the surface layer at a speed of $0,242 \mathrm{~m} / \mathrm{s}$ with to southwest direction $\left(207.8^{\circ}\right)$, the smallest current velocity was in bottom layer is $0.141 \mathrm{~m} / \mathrm{s}$ with southwest directiont $\left(207^{\circ}\right)$. Based on $2 D$ hydrodynamic model simulation indicated that when high tide ocean current was flowed to the mainland (south) when low tide the current was flowed to the open sea direction. Based on the content grain size of the sediment, the studi area consisted of sand $(64.98-72.15 \%)$ the highest sand fraction at station $B$ (rare of geotextile), silt $(24.56-29.36 \%)$ the highest silt fraction at station $C$ (front of geotextile) andclay (1.64 -5.64\%) the highest clay fraction at station C(front of geotextile)

Key Words: Current, Muara Kamal Shoreline, Sediment, 2D hydrodynamics model 


\section{PENDAHULUAN}

Pantai Muara Kamal merupakan salah satu pantai yang terletak di Teluk Jakarta, yang mengalami perubahan fisik pantai berupa erosi. Erosi terjadi apabila di suatu pantai mengalami kehilangan atau pengurangan sedimen artinya sedimen yang terangkut lebih besar dibandingkan yang diendapkan [11]. Wilayah pesisir pantai Muara Kamal merupakan tempat aktivitas masyarakat setempat seperti budidaya perikanan dan tempat pelelangan ikan. Permasalahan erosi yang terjadi di perairan pantai Muara Kamal dapat menjadi ancaman bagi aktivitas tersebut sebagai sumber mata pencaharian masyarakat setempat. Usaha perlindungan pantai di Muara Kamal sudah dilakukan dari beberapa tahun yang lalu yaitu dengan membangun tanggul sederhana untuk mempertahankan garis pantai agar tidak tererosi. Sedangkan dalam kurun waktu dua tahun terakhir di perairan Pantai Muara Kamal diterapkan pelindung pantai tipe tenggelam dengan bahan geotekstil yang bertujuan untuk menangkap atau mengendapkan sedimen agar dapat menambah garis pantai baru. Geotekstil merupakan material non woven geotextile yang berbentuk seperti sebuah silinder panjang atau guling dengan berbagai ukuran panjang, lebar dan tinggi sesuai kebutuhan dan kondisi di lapangan. Geotekstil dapat diisi dengan material pengisi seperti pasir, kerikil dan mortar.

Sebaran dan endapan sedimen disuatu perairan laut dekat pantai dipengaruhi oleh pasang surut, arus dan gelombang. Gelombang yang merambat menuju pantai dengan sudut tertentu terhadap garis pantai, setelah pecah dapat menimbulkan arus sepanjang pantai (longshore current). Arus tersebut dapat mengakibatkan transpor sedimen sepanjang pantai (longshore transport). Sedangkan arus yang dibangkitkan oleh pasang surut menyebabkan proses transpor asimetrik akibat adanya dua arah arus yang berlawanan yaitu arus ke arah daratan saat air laut bergerak pasang (flood tide) dan arus ke arah laut saat air laut bergerak surut ( $e b b$ tide). Gerakan aliran ini sangat berperan pada resuspensi dan pergerakan sedimen baik ke arah daratan maupun ke arah laut [4]. Oleh karena itu untuk mengetahui pola arus dan sedimen di sekitar geotekstil yang mempunyai pengaruh terhadap proses pantai di perairan Pantai Muara Kamal Jakarta Utara perlu dilakukan penelitian yang bertujuan untuk mengkaji pola arus dan sedimen yang terjadi di perairan Pantai Kamal Muara Jakarta Utara.

\section{METODOLOGI}

\subsection{Tempat dan Waktu Penelitian}

Penelitian dilakukan pada 5 Oktober 2012 di kawasan perairan Pantai Muara Kamal Jakarta Utara. Materi utama pada penelitian adalah arus laut dan sampel sedimen yang diambil dari titik pengambilan sampel yang terletak didepan atau disebelah utara geotekstil yaitu titik $\mathrm{C}$ dan $\mathrm{D}$, dan dibelakang atau disebelah selatan yitu titik A dan B (lihat Gambar 1). Bangunan pelindung pantai tenggelam geotekstil tipe ganda dapat diperlihatkan pada Gambar 1. Sedangkan penentuan posisi lokasi menggunakan Global Positioning System (GPS) diperlihatkan pada Tabel 1.yang mewakili kondisi perlindungan pantai di perairan Pantai Muara Kamal Jakarta Utara.

Tabel 1. Nama stasiun dan posisi pengambilan sampel sedimen

\begin{tabular}{llll}
\hline No. & \multicolumn{1}{c}{ Lokasi } & Bujur & Lintang \\
\hline 1 & Stasiun A (Belakang Geotekstil) & 106.726355 & -6.09202 \\
2 & Stasiun B (Belakang Geotekstil) & 106.726513 & -6.09212 \\
3 & Stasiun C (Depan Geotekstil) & 106.726439 & -6.09179 \\
4 & Stasiun D (Depan Geotekstil) & 106.726642 & -6.09189 \\
\hline
\end{tabular}




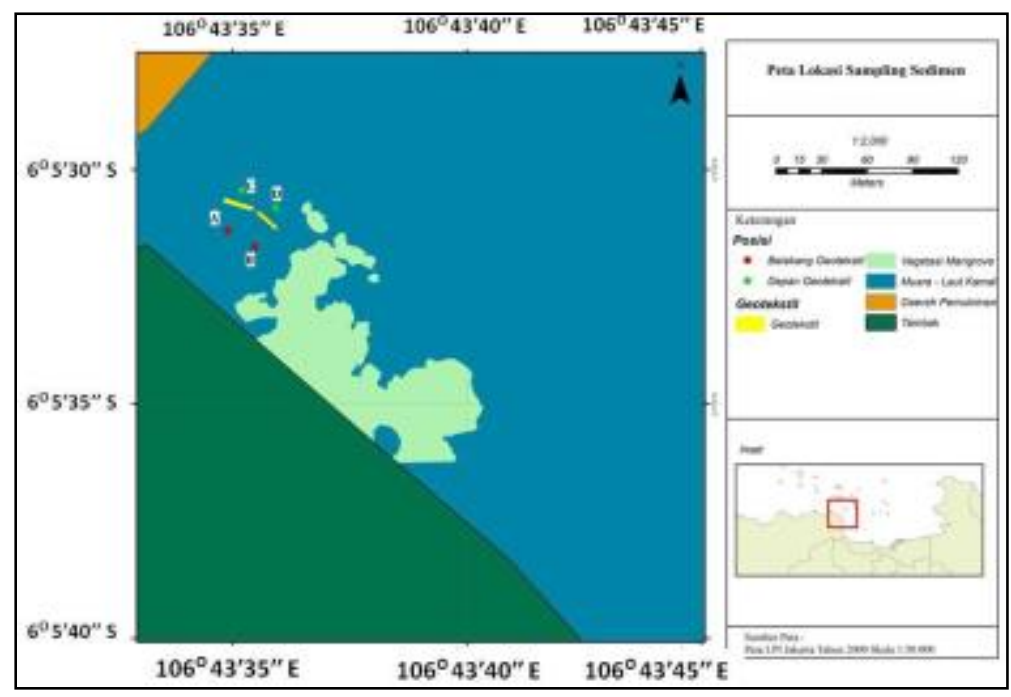

Gambar 1. Lokasi Penelitian

\subsection{Metodologi Penelitian}

Diagram alir pelaksanaan penilitian dapat dilihat pada Gambar 2. Sampel sedimen diambil dengan menggunakan grab sampler, kemudian sedimen diklasifikasikan menurut ukuran butir [2].Pengukuran arus dipilih satu lokasi sebagai stasiun tetap yang dilakukan selama 1 × 24 jam dengan interval 10 menit pada tanggal 5Oktober 2012. Menurut Poerbandono dkk. [10] pengukuran arus minimal dilakukan selama 1 hari untuk pasut bertipe campuran. Alat yang digunakan adalah ADCP (Acoustic Doppler Current Profiler) Argonout SonTek XR.Pasang surut diukur dengan pengamatan langsung dilapangan selama 1 piantan (15 Hari) dengan menggunakan palem pasut. Sedangkan data sekunder berupaPeta LPI (Lingkungan Pantai Indonesia) tahun 2000 skala 1:500.000 dari Badan Informasi Geospasial (BIG) dan citra satelit Google Earth tahun 2009 digunakan dalam pembuatan model hidrodinamika 2D menggunakan software SMS 8.1.Model SMS 8.1 dengan model 2D yang digunakan adalah modul ADCIRC (Advance Circulation) dengan domain model yang digunakan adalah dengan metode finite element, dimana faktor pembangkitnya yang digunakan sebagai masukan model adalah pasang surut dengan menggunakan 9 konstanta pasang surut $(\mathrm{K} 1, \mathrm{~K} 2, \mathrm{M} 2, \mathrm{~N} 2, \mathrm{O} 2, \mathrm{P} 2, \mathrm{~S} 2)$. Persamaan matematika yang digunakan model dalam penyelesaian model 2D disusun berdasarkan persamaan kontinunitas dan momentum yang diintegrasikan terhadap kedalaman. Skenario model yang dijalankan dengan kondisi domain dibangun dengan mesh segitiga tidak teratur yang dibangun dari garis pantai dan batimetri yang didapatkan dari peta LPI dengan skala 1:50000. Waktu yang diskenariokan selama 15 hari dari waktu pengukuran, dengan inputan garis pantai dan batimetri, dan faktor pembangkit pasang surut yang berasal dari peramalan modul model sendiri. 


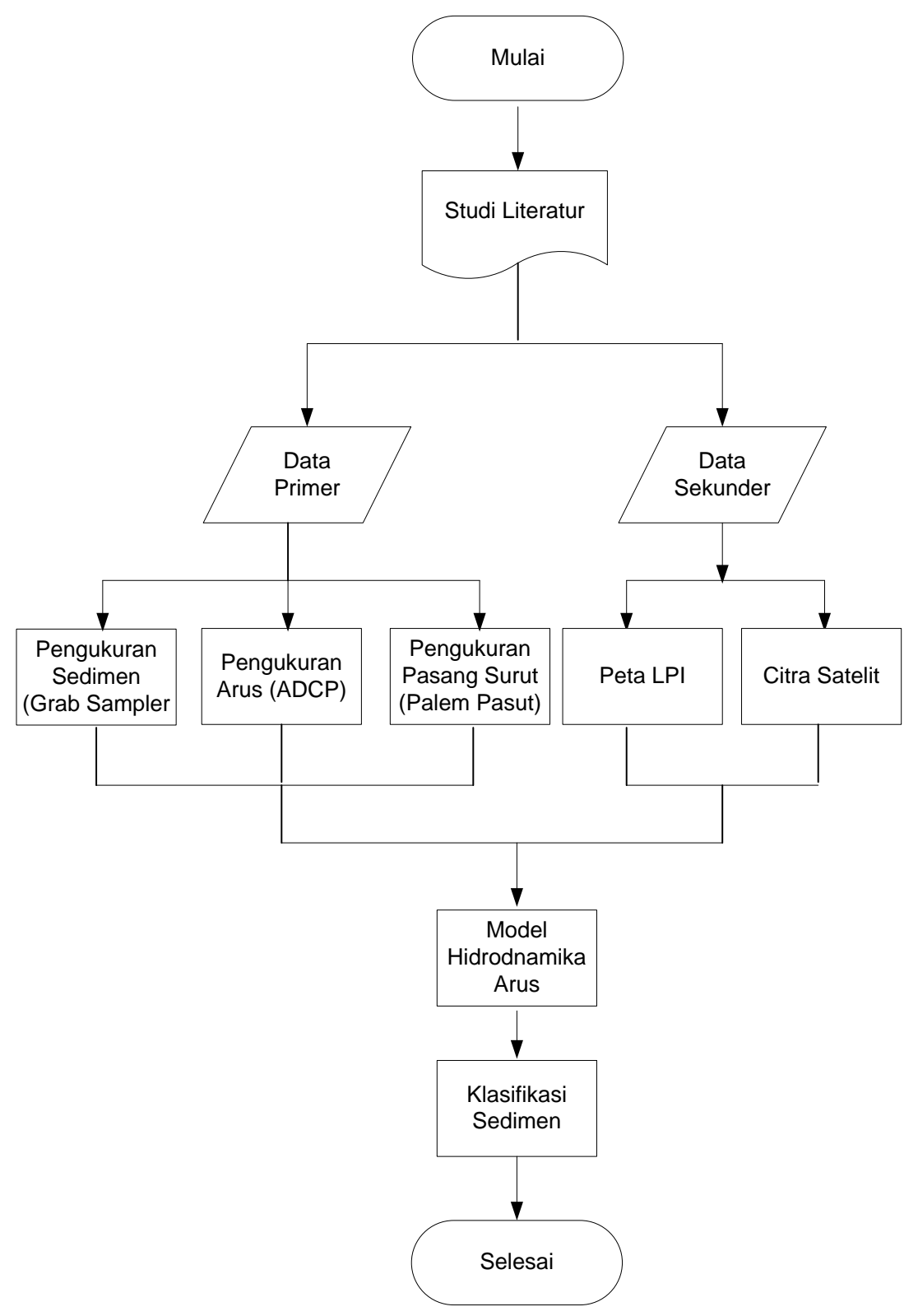

Gambar 2. Diagram Alir Penelitian

\section{HASIL DAN PEMBAHASAN}

\subsection{Hasil Pengukuran Arus}

Berdasarkan pengukuran lapangan diperoleh kecepatan arus maksimum dan minimum pada tiap - tiap lapisan. Setiap lapisan pada pengukuran arus dibagi menjadi 3 lapisan, setiap lapisan dibagi menjadi 2cell, dan cell dihitung dari dasar dekat ADCP. Adapun cellnya adalah yang dihitung mulai dekat dasar hingga permukaan cell 1 dan cell 2lapisan dasar, cell 3 dan cell 4 lapisan tengah, cell 5 dan cell 6 lapisan permukaan dengan kedalaman total adalah 8 meter. Pembagian ini dimaksudkan untuk lebih memberikan informasi kecepatan dan arah arus yang mewakili setiap kolom air di perairan Pantai Kamal Muara Jakarta Utara. Kecepatan arus rata-ratadan arah arus pada setiap lapisan dapat diperlihatkan pada Tabel 2. 
Tabel 2. Kecepatan dan Arah Arus Perairan Muara Kamal.

\begin{tabular}{lccc}
\hline \multicolumn{1}{c}{ Lapisan } & $\begin{array}{c}\text { Kecepatan Arus } \\
(\mathbf{m} / \mathbf{s})\end{array}$ & \multicolumn{2}{c}{ Arah Arus $\left.\mathbf{(}^{\mathbf{9}}\right)$} \\
\cline { 2 - 4 } & Maksimal & Maksimal & Minimal \\
\hline Dasar ( cell 1 dan 2$)$ & 0,141 & 207 & 180 \\
\hline Tengah (cell 3 dan 4) & 0,205 & 209.8 & 315 \\
\hline Permukaan (cell 5 dan 6) & 0,242 & 207.8 & 270 \\
\hline
\end{tabular}

Arus di lapisan permukaan, tengah dan dasar perairan Pantai Kamal Muara jakarta Utara dipengaruhi kuat oleh arus pasang surut. Hal tersebut sesuai dengan pernyataan Kim [7] bahwa arus diperairan teluk dan laguna sangat dipengaruhi oleh pasang surut. Dari Tabel 2 dapat dilihat bahwa kecepatan arus yang paling besar terdapat pada lapisan permukaan dan kecepatan paling kecil terdapat pada lapisan dasar. Hal ini disebabkan karena pengaruh pasang surut dan pengaruh gesekan angin memberikan kontribusi pada kecepatan di permukaan perairan, disamping perbedaan waktu perubahan kondisi elevasi menciptakan lapisan permukaan memiliki kecepatan lebih besar dibandingkan dengan lapisan dasar. Hal ini dipengaruhi oleh gaya gesek dasar yang memberi arah vektor yang berlawanan dengan arah vektor arus yang dibangkitkan oleh pasang surut sehingga pada dasar perairan cenderung kecepatan arus lebih kecil. Sedangkan kecepatan arus pada lapisan permukaan lebih cepat diakibatkan kontribusi gaya gesek angin yang memberi resultan vektor yang searah dengan arus yang didominasi oleh pasang surut. Hasil verifikasi arus lapangan dengan arus model diperlihatkan pada Gambar 3.

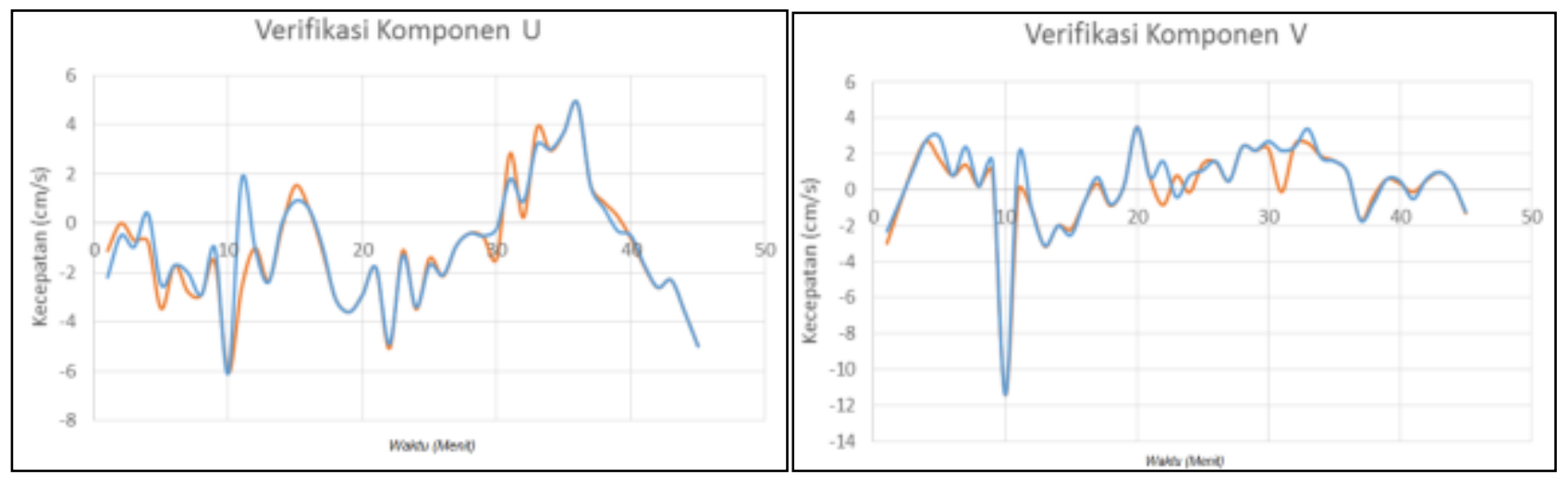

Gambar 3. Hasil Verifikasi Arus Lapangan dengan Model

Data hasil model (warna orange) yang diverifikasi dengan hasil pengukuran lapangan (warna biru) dengan nilai RME untuk komponen U adalah sebesar 12,27\% dan hasil verifikasi untuk komponen V adalah 19,89\% nilai eror yang dihasilkan model terhadap hasil lapangan terjadi akibat beberapa penyederhanaan yang dilakukan pada model agar meminimalisir kondisi blow up pada model, sehingga dari penyederhanaan tersebut, maka nilai RME untuk komponen $\mathrm{U}$ dan $\mathrm{V}$ dapat dijadikan representasi pada gambaran perairan.

\subsection{Hasil Pengukuran Pasang Surut}

Data pasang surut perairan Pantai Kamal Muara Jakarta Utara diolah dengan menggunakan worldtide untuk mendapatkan komponen pasang surut dan menentukan tipe pasang surut di perairan Pantai Muara Kamal. Secara kualitatif, tipe pasut suatu perairan dapat ditentukan oleh nisbah (perbandingan) antara amplitudo (tinggi gelombang) unsur-unsur pasut tunggal utama dengan amplitudo unsur-unsur pasut ganda utama. Melalui pengamatan yang dilakukan selama 15 hari, pasang surut di perairan Pantai Muara Kamal Jakarta Utara memiliki komponen pasang surut yang dapat diperlihatkan pada Tabel 3. Tipe pasang surut di perairan Pantai Muara Kamal Jakarta Utara adalah harian tunggal yang didapatkan dari hasil analisis komponen pasang surut dengan nilai Formzall F > 3,0 grafik pasut dapat diperlihatkan pada Gambar 4 
Tabel 3. Komponen Pasang Surut Perairan Pantai Muara Kamal

\begin{tabular}{ccc}
\hline Komponen & Amplitudo & Phasa \\
\hline O1 & 0,158 & 89,09 \\
P1 & 0,202 & 117,15 \\
K1 & 0,386 & 137,77 \\
N2 & 0,062 & 150,12 \\
M2 & 0,023 & 253,14 \\
S2 & 0,124 & 88,57 \\
K2 & 0,187 & 150,43 \\
M4 & 0,006 & 65,26 \\
MS4 & 0,016 & 170,34 \\
SO & 0,772275 & -
\end{tabular}

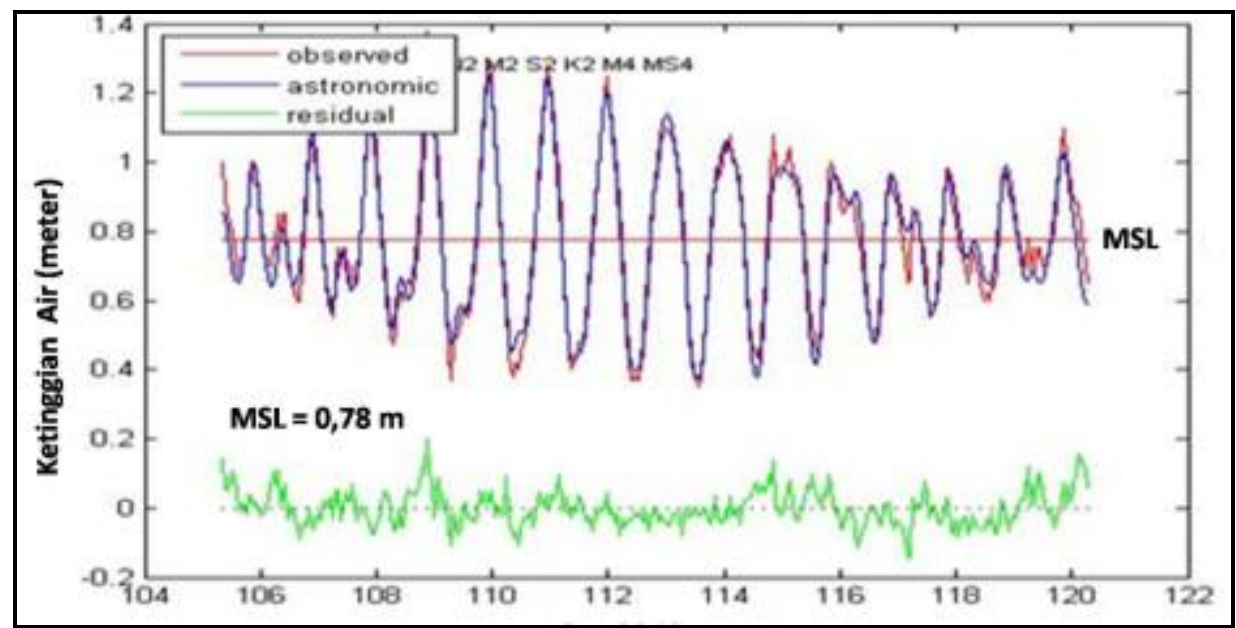

Gambar 4. Grafik Pasang Surut

Pada Gambar 4 dapat dilihat grafik elevasi muka air selama pengamatan pasang surut dilakukan, terlihat pada grafik pengamatan dilakukan dimulai dari kondisi purnama dan diakhiri pada kondisi perbani. Nilai MSL elevasi muka air terlihat pada gambar bernilai $0,78 \mathrm{~m}$. Perubahan elevasi yang terjadi secara umum memiliki nilai residual yang dibangkitkan atau diciptakan oleh kondisi morfologi perairan serta aktifitas perairan laut yang cukup ramai, terlihat pada garishijau merupakan grafik nilai residual yang diberikan pada perubahan elevasi air yang terjadi. Pemisahan nilai elevasi ini bertujuan untuk mengetahui pengaruh nontidal terhadap perubahan elevasi muka air.

\subsection{Hasil Pemodelan Arus}

Simulasi arus diperairan Pantai Kamal Muara Jakarta Utara yang dibangkitkan oleh pasang surut hasilnya diperlihatkan pada Gambar 5.a dan 5.b 

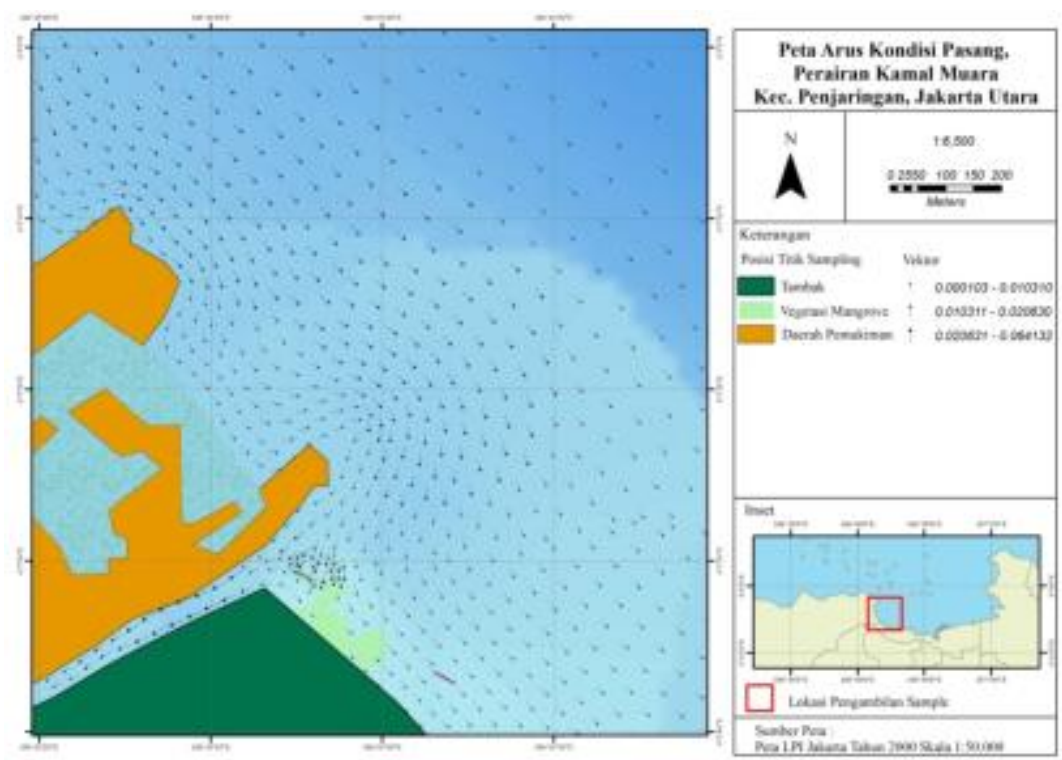

Gambar 5a. Peta Pola arus perairan Pantai Kamal Muara pada Saat Pasang
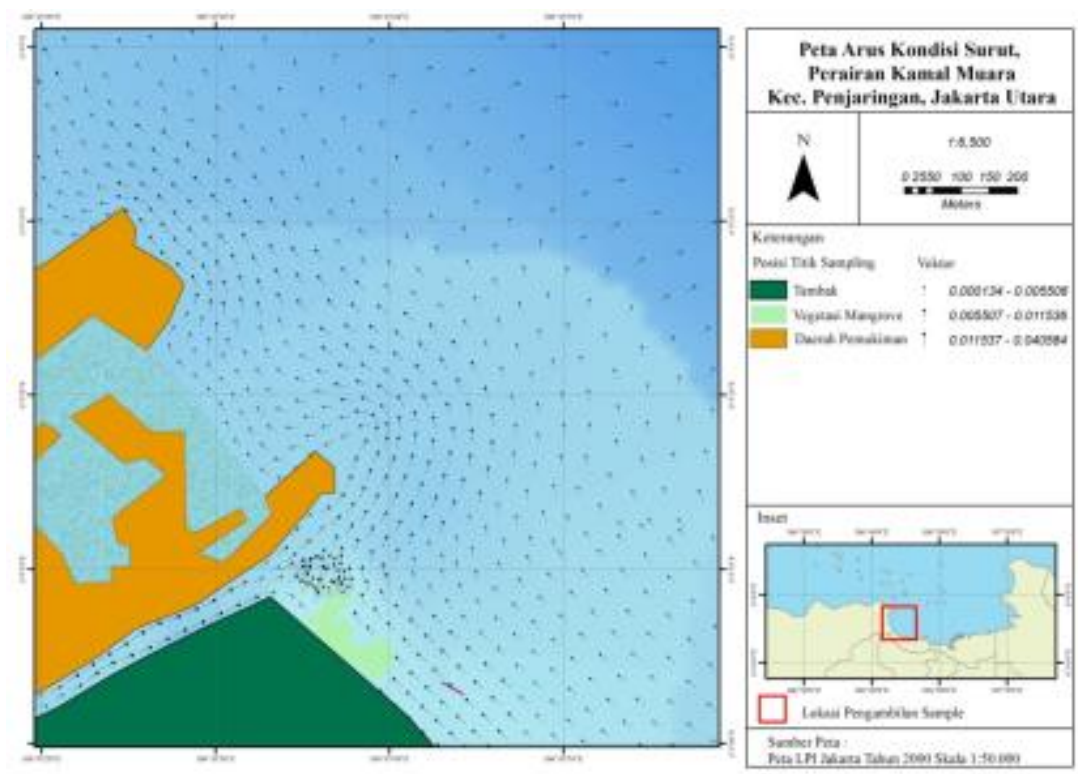

Gambar 5b. Peta Pola arus perairan Pantai Kamal Muara pada Saat Surut

Pantai Muara Kamal memiliki struktur kemiringan (morfologi) landai, sehingga memiliki gelombang pecah dengan tipe tumpah, yang akan mengangkut sedimen dan mengendapkannya di pantai [11]. Berdasarkan hasil pemodelan 2D dengan dukungan software SMS 8.1. diperoleh pola arus pada saat pasang bergerak dari arah barat laut menuju ke arah selatan kemudian bergerak mengarah sejajar pantai (Gambar 5a). Sedangkan pada saat surut arus bergerak kearah sebaliknya yaitu bergerak dari arah selatan menuju ke arah barat laut atau bergerak ke arah laut (Gambar 5b). Hasil simulasi pemodelan 2D juga diperlihatkan adanya pengumpulan pola arus laut di sekitar bangunan pelindung pantai geotekstil di Muara Kamal Jakarta Utara. Hal ini dapat mengurangi laju arus laut baik pada saat pasang dan pada saat surut, sehingga dapat menghambat laju distribusi sedimen yang ikut terbawa oleh arus laut dan mengendapkan sedimen di sekitar geotekstil.

\subsection{Hasil Distribusi Sedimen Di Muara Kamal}

Ukuran butir sedimen berdasarkan klasifikasi Shepard pada tiap-tiap stasiun di depan dan di belakang geotekstil disajikan pada Tabel 4. 
Tabel 4. Hasil analisis parameter sedimen dan penamaan jenis sedimen.

\begin{tabular}{lcccc}
\hline & & \multicolumn{3}{c}{ Ukuran Butir (\%) } \\
\cline { 3 - 5 } \multicolumn{1}{c}{ Nama Stasiun } & Kode & $\begin{array}{c}\text { Pasir } \\
\text { (Sand) }\end{array}$ & $\begin{array}{c}\text { Lanau (Silt) } \\
0.0625-\end{array}$ & $\begin{array}{c}\text { Lempung } \\
\text { (Clay) }\end{array}$ \\
& & $2-0.125 \mathrm{~mm}$ & $0.0078 \mathrm{~mm}$ & $0.0039 \mathrm{~mm}$ \\
\hline Stasiun A Belakang Geotekstil & $\mathrm{A}$ & $69.432 \%$ & $28.926 \%$ & $1.642 \%$ \\
Stasiun C Depan Geotekstil & $\mathrm{C}$ & $64.986 \%$ & $29.361 \%$ & $5.653 \%$ \\
Stasiun B Belakang Geotekstil & $\mathrm{B}$ & $72.156 \%$ & $24.560 \%$ & $3.285 \%$ \\
Stasiun D Depan Geotekstil & $\mathrm{D}$ & $66.867 \%$ & $28.010 \%$ & $5.123 \%$ \\
& & & & \\
\hline
\end{tabular}

Dari Tabel 4 dapat dilihat bahwa klasifikasi sedimen di perairan Pantai Muara Kamal terdiri dari pasir, lanau dan lempung. Sedimen yang paling dominan yang tertahan atau terperangkap oleh keberadaan penahan gelombang geotekstil adalah sedimen tipe pasir. Fraksi pasir (sand) tertinggi didapatkan di stasiun B di belakang geotekstil dengan nilai (72.156\%) dan paling rendah didapatkan di stasiun C di depan geotekstil dengan nilai (64.986\%). Fraksi lanau (Silt) berkisar antara 24,56 - 29,36\%, dengan nilai persentase terbesar didapatkan pada stasiun $C$ yaitu di depan geotekstil dan terendah pada stasiun B yaitu di belakang geotekstil dengan nilai $(24,56 \%)$. Sedangkan untuk fraksi lempung (Clay) mempunyai nilai berkisar antara $1.64-5.653 \%$, persentase tertinggi didapatkan pada stasiun $\mathrm{C}$ yaitu di daerah depan geotekstil, sedangkan presentase terendah terdapat di stasiun A yaitu di belakang geotekstil dengan nilai $1.64 \%$. Perbedaan distribusi sedimen pada masing-masing stasiun dikarenakan faktor kecepatan arus, dimana kecepetan arus pada lapisan dasar lemah, sehingga pengadukan fraksi pasir yang berada pada lapisan bawah tidak terjadi. Endapan yang terjadi secara terus menerus dapat menambah garis pantai baru.

\section{SIMPULAN}

Berdasarkan hasil penelitian didapatkan pola arus di perairan Pantai Muara Kamal Jakarta Utara pada saat pasang mengarah dari barat laut ke selatan, sedangkan pada saat surut bergerak sebaliknya dari selatan menuju barat laut. Kecepatan arus pada lapisan dasar sebesar 0,141 m/det merupakan kecepatan arus yang lemah dibandingkan dengan kecepatan pada lapisan permukaan maupun tengah, hal ini terkait dengan besarnya fraksi pasir yang terkandung dalam sedimen dasar dibandingkan dengan nilai fraksi lainya. Lemahnya arus, membuat pengadukan pada lapisan bawah hanya terjadi pada butir sedimen berupa lanau maupun lempung. Jenis sedimen di perairan Pantai Muara kamal Jakarta Utara yaitu pasir, lanau dan lempung, fraksi pasir tertinggi didapatkan di stasiun B belakang geotekstil dengan nilai $72.156 \%$, fraksi lanau tertinggi didapatkan di stasiun $\mathrm{C}$ yaitu di depan geotekstil 29,36\% dan Fraksi lempung tertinggi didapatkan pada stasiun $\mathrm{C}$ yaitu di daerah depan geotekstil dengan nilai $5.653 \%$.

\section{DAFTAR PUSTAKA}

[1] Andayani, Ariani. (2012). Uji coba Pemasangan Karung Geotekstil Memanjang di Pantai Kamal Muara Jakarta Utara. Jurnal Kelautan Nasional Vol.7 Desember 2012.

[2] Buchanan (1984) dalam Prasetyo (2009). Studi Pola Transport Sedimen Untuk Mendukung Perencanaan Pengembangan Pelabuhan Di Perairan Teluk Bayur Padang. FPIK Undip Semarang $119 \mathrm{hlm}$.

[3] Chairul Paotonan, (2012). Metode Sederhana Penentuan Dimensi Geotekstil sebagai struktur pelindung pantai.Jurnal Riset dan Teknologi Kelautan. Vol 10 No 2 Juli-Desember 2012.

[4] Dyer, K.R. (1990). Coastal and Estuarine Sediment Dynamics, John Wiley \& Sons, 1990 
[5] Hadikusumah, (2009). Karakteristik Gelombang Dan Arus Di Eretan, Indramayu makara, Sains. Vol. 13, No. 2, November 2009: pp 163-172.

[6] Hendra, Permana, 2012. Kajian Kondisi Arus Pada Saat Musim Timur Di Perairan Semarang -Demak. Journal of Ocenografi. Vol. 1 No. 1 2012."

[7] King, C. A. M. (1966). An Introduction to Oceanography. McGraw Hill Book Company, Inc. New York. San Francisco.

[8] Latief, H. K. (2002). Oseanografi Pantai. ITB, Bandung.

[9] Pariwono, J.I. (1998). Kondisi Oseanografi perairan pesisir Lampung. Proyek pesisir publication, Techical Report (TE-99/12-I) Coastal Research Center. University of Rhode Island, Jakarta, Indonesia, 24pp. (In Indonesian). 1998.

[10] Poerbandono dan Djunarsah, E. (2005). Survei Hidrografi. Refika Aditama. Bandung.

[11] Triatmodjo, B. (1999). Teknik Pantai. Betta Offset, Yogyakarta. 397 pp.1999 